\title{
USOS DO DUPLO SENTIDO NA MÚSICA POPULAR DO BRASIL: ALGUMAS NOTAS SOBRE O CORPO DAS BAIANAS
}

\section{USES OF DOUBLE MEANING IN POPULAR MUSIC OF BRAZIL: SOME NOTES ON THE BODY OF BAIANAS}

\author{
Francisco Antonio Nunes Neto ${ }^{1}$
}

\begin{abstract}
Resumo: Tomando como referência algumas dentre as muitas composições do cancioneiro popular produzidas no Brasil entre os anos 30 e 90 do século XX, este artigo discute, de maneira introdutória e preliminar, o uso do recurso do duplo sentido em composições musicais que têm o corpo das baianas como objeto, tema e elemento de inspiração a partir dos binômios: corpo e sensualidade, corpo e comida e corpo e religiosidade.
\end{abstract}

Palavras-Chave: Música popular, Baianas, Corpo, Duplo sentido.

Abstract: Referring to some of the many compositions of popular music produced in Brazil from the 30-ies through the 90-ies years of the twentieth century, this article discusses, in a introductory and preliminary way, the use of the double meaning in musical compositions that have, as their object, theme and source of inspiration, the body of women of Bahia ("Baianas"), by juxtaposing the binomials: body and sensuality, body and food, and body and religiosity.

Keywords: Popular music, Baianas, Body, Double meaning.

\section{INTRODUÇÃO}

Embora a proposta temática deste artigo pareça pretensiosa, neste texto não argumentaremos sobre a totalidade de representações (CHARTIER, 1990), já elaboradas no Brasil sobre

\footnotetext{
${ }^{1}$ Doutor em Cultura e Sociedade/UFBA-IHAC. E-mail: xicco7@ hotmail.com.
} 
as baianas na música popular, posto que se revelaria uma tarefa inexequível em um texto cujo fôlego é breve. Dessa maneira, apresentaremos, ainda que introdutoriamente, algumas dentre as muitas composições do cancioneiro popular produzidas no país entre os anos 30 e 90 do século XX que tomam as baianas como objeto, tema e elemento de inspiração a partir da utilização do recurso do duplo sentido com o uso dos binômios: corpo e sensualidade, corpo e comida e corpo e sensualidade. Estas chaves nos possibilitarão problematizar como - através da história social da música popular do Brasil - as práticas culturais e os sujeitos das classes populares são dados a ler.

Neste sentido, para os fins que se destina este texto, foram analisadas algumas composições musicais, elaboradas por Ary Barroso, Herivelto Martins, Roberto Martins, Pedro de Sá Pereira, Gastão Viana e Benedito Lacerda, Humberto Porto, Dorival Caymmi, Vicente Paiva, Geraldo Pereira, Moreira da Silva, Manezinho Araújo, Denis Brean, Pedro Caetano, assim como aquela, elaboradas por Joel Almeida, Bala e Manoel, Baden Powell, Vinicius de Moraes, Riachão, Gilberto Gil, Osmar Macedo, Moraes Moreira, Caetano Veloso e Lucas Santana. Composições que ganharam notoriedade nas interpretações de artistas como Aracy Cortes, Elisa Coelho, Silvio Caldas, Chiquinha Jacobina, Carmem Miranda, Dircinha Batista, Aurora Miranda, Dalva de Oliveira, Chiquinho Sales, Heleninha Costa, Isaura Garcia, Linda Batista, Marta Rocha, Emilinha Borba, Anjos do Inferno, Trio de Ouro, Trio Nordestino, Paulinho Boca de Cantor, Gal Costa, quando não, por eles próprios. Entretanto, face ao volumoso número de composições musicais identificadas, relativas ao período histórico de que trata a proposição deste artigo, trabalharemos apenas com algumas letras analisadas, que serão apresentadas nas páginas seguintes.

Na história social da música popular do Brasil, podemos dizer que a utilização das baianas como tema, objeto e elemento de inspiração, em larga medida, primeiramente, se relaciona com a insurgência, contribuições e influências que as Tias Baianas passaram a exercer no processo de reconfiguração, reorientação, reestruturação e reordenamento das práticas culturais populares, subalternas, no Rio de Janeiro a partir de meados do século XIX em lugares como Cidade Nova, Saúde e na região do Cais do Porto. Ali elas se inscreveram com relativa força no imaginário social de uma localidade que entrou para a história do Rio de Janeiro como a Pequena África (MOURA, 1995). 
As baianas, mulheres negras como a Tia Ciata, de cujas casas se converteram em locus de produção musical, passaram - por conta do respeito e admiração que conquistaram - a protagonizar letras de muitas músicas produzidas na então capital do país como espécies de “musas inspiradoras". Neste sentido, podemos afirmar haver uma quantidade expressiva de composições do cancioneiro popular brasileiro - produzidas entre as décadas de 30 e 90 do século passado - que se refere às baianas, seja na Festa do Senhor do Bonfim de Salvador, nos tabuleiros seculares, ainda visualizáveis na Cidade do Salvador, ou simplesmente as baianas nascidas em Salvador e cidades do Recôncavo. (NUNES NETO, 2013)

Portanto, não se constitui risco afirmar que no Brasil as baianas - diferentemente das paulistas, cariocas, mineiras e sulistas - são as que, historicamente, inscreveram-se no imaginário das práticas de composição musical do país por congregarem elementos das tradições de matrizes africanas e afro-baianas, relacionados aos discursos de uma ancestralidade referente às origens da formação cultural brasileira. Pelo símbolo que se constituem e/ou ocupam no imaginário popular no Brasil, somado à vasta produção musical que as toma como tema, notamos haver lacunas a serem preenchidas através de outras investidas de pesquisas (o que configura esta possibilidade temática como um profícuo campo de atuação para os desejosos estudiosos das práticas culturais brasileiras).

Para os fins a que se destina este artigo, nos limitamos a apresentar algumas composições musicais, através das quais é possível notar o fascínio que as baianas parece ter exercido entre compositores e intérpretes no Brasil. Embora o marco temporal, o contexto histórico em que se inscrevem as composições analisadas para esse artigo - sejam os anos 30 do século XX, o ano de 1917 se revela como demarcador histórico em que as contribuições das Tias Baianas, no âmbito da produção musical no Rio de Janeiro, ganharam novos contornos e outras visibilidades. Aquele ano registra a gravação de Pelo Telefone, considerado o primeiro samba gravado no Brasil, estando seu nascimento inscrito nos limites das casas das Tias Baianas. Sobre a propriedade dessa composição há inúmeras controvérsias, inclusive, se se trata ou não de um samba enquanto gênero musical. Neste sentido, na Pequena África,

[...] entre os frequentadores da casa dessa Tia Ciata (...) contavam-se Sinhô, Pixinguinha e Donga, este último autor da música "Pelo Telefone", a primeira gravada com a indicação de samba em 1917. Acha mesmo Lúcio Rangel que o samba é um só - escrevendo a propósito, em seu livro Sambistas e 
Chorões: "Os amantes de classificações mais ou menos arbitrárias falam de samba de morro, como o da primeira fase, samba da cidade, segunda etapa, esquecendo-se de que a subida ao morro, das populações da cidade, por motivos única e exclusivamente econômicos, só se deu depois do aparecimento oficial do primeiro samba". Entretanto, o novo gênero musical popular não se fixou logo de forma perfeita, nem sua denominação se impôs de pronto. $\mathrm{O}$ famoso conjunto Oito Batutas - que se organizou em 1919 e chegou a se exibir na Europa em 1922 - reunindo Pixinguinha, Donga e outros instrumentistas da época, incluía em seu repertório básico apenas lundus, maxixes, batuques, cateretês e canções sertanejas. Quanto ao gênero de música elaborado ou definido entre os frequentadores da casa da Tia Ciata - o samba carioca, profundamente urbano - Oneida Alvarenga observa que pode ser considerado uma derivação do maxixe, pois o "Pelo Telefone" de Donga, bem como as peças de autoria de Sinhô, pouco se distinguiam dos maxixes cantados (Diário de Notícias, 13 de janeiro de 1968, p. 07).

A gravação de Pelo Telefone se inscreve num contexto em que as Tias Baianas representavam no Rio de Janeiro a tradição e a ancestralidade cultural de matriz afro-baiana. Por esse motivo, a Bahia e as baianas, não por um acaso, passaram a ocupar lugar de relativo destaque entre os compositores da música popular do Brasil. É necessário lembrar que, naquele contexto, as favelas e morros do Rio de Janeiro se configuravam como lugares onde os encontros musicais ganharam novos sentidos, posto que deles tomaram lugar membros de diversas condições e classes sociais, ali proporcionando o estabelecimento de uma intensa circularidade cultural - entre os diversos níveis de cultura, ali presentes. (GINZBURG, 1998)

Em As Donas do Canto, Marilda Santanna apresenta pistas importantes sobre o contexto histórico em que as baianas passaram a figurar nas representações musicais sobre a Bahia, entre os compositores-intérpretes: em plena cena cultural do Rio de Janeiro. Segundo argumenta, em suas análises sobre a baiana enquanto um arquétipo, podemos citar o seguinte:

[...] a construção da figura da baiana/mulata nos palcos e no cancioneiro popular aponta para a sensualidade, que abrange o duplo sentido e as danças impressas nos corpos sensuais e olhares; para a etnicidade, impressa nas matrizes que vão da preta, morena, mulata, cabocla, cafuza, dentre outras; e para a culinária, indissociável da sensualidade e do duplo sentido das letras; para a indumentária, carregada de significados religiosos que vão se diluindo à medida que vão se re-inventando; e para a performance (...) Entretanto, esta construção normalmente se estende ao próprio tipo de mulher brasileira, construído de fora para dentro e de dentro para fora como uma figura dotada de sensualidade e malícia "naturalizada", bem como um corpo dotado dos ingredientes também encontrados na construção da figura da baiana (SANTANNA, 2009: 152 - grifos meus). 
Pontos de Interrogação, v. 3, n. 2, jul./dez. 2013

Revista do Programa de Pós-Graduação em Crítica Cultural

Universidade do Estado da Bahia (UNEB), Campus II - Alagoinhas - BA

Uma pequena observação a partir da citação anterior pode ser vista em epígrafe. Notamos que Santanna utiliza em sua argumentação a palavra matriz para se referir à cor da pele, ao fenótipo. Entretanto, penso que ao invés de matrizes, a autora poderia - sem perda do sentido que quer veicular com a informação - utilizar a palavra "matizes", uma vez que o termo "matriz", tal como utilizado por uma vertente da Antropologia, vincula-se à etnia, ao passo que "matiz" - como utilizado por outros cientistas sociais - refere-se à cor da epiderme. Dessa maneira, a ideia de matriz parece se relacionar com etnia, enquanto categoria analítica e, neste caso, preta, morena, mulata, cabocla e cafuza são categorias comumente utilizadas na definição da epiderme, portanto, "raça".

Levando-se em consideração as pistas abertas por Marilda Santanna sobre a utilização do duplo sentido entre os compositores do cancioneiro popular e tomando como referência os elementos grifados na citação anterior, guardando-se as devidas proporções sobre o contexto histórico em que as composições musicais que serão apresentadas foram criadas, enfocaremos os seguintes binômios: i) corpo e sensualidade, ii) corpo e comida e iii) corpo e religiosidade, posto que, majoritariamente, são os elementos-chave que mais foram utilizados pelos compositores que elaboraram algumas formas de representação sobre as baianas na música popular do Brasil. Igualmente, as baianas também foram tomadas em muitas composições musicais como vetores através dos quais algumas representações sobre a Bahia foram tecidas.

\section{CORPO E SENSUALIDADE}

Como pontuado por Marilda Santanna, o duplo sentido como recurso estético na linguagem musical é passível de verificação no cancioneiro popular brasileiro nas composições que tomam a baiana como tema central ou sobre ela é feita alguma menção secundária. Dessa maneira, para a escrita deste artigo, a utilização dos binômios, pares analíticos, nos ajudará a problematizar como o duplo sentido foi recorrentemente utilizado entre os compositores. Relativo à Bahia, historicamente, a maior parte das representações sobre as baianas no âmbito das músicas que se consagraram, invariavelmente, justapõe corpo e sensualidade como elementos indissociáveis. A justaposição destes elementos remonta na história deste país à condição social imposta às mulheres negras, africanas e/ou afro-brasileiras, que, na condição de escravizadas nos limites da casa-grande, ali foram tomadas como alvo da cobiça entre os se- 
nhores de escravos que, por muitas vezes, de maneira torpe, invasiva e violenta, abusaram sexualmente daquelas mulheres, cujos corpos eram entendidos e tratados como extensão de suas propriedades (SANCHES, 1998).

Aqui nos interessa pensar apenas como - em decorrência da presença e importância que as Tias Baianas alcançaram no Rio de Janeiro - elas emergiram no cancioneiro popular brasileiro na qualidade de merecedoras de diversas formas e tipos de citação nas inúmeras composições musicais. Ainda não há - entre as pesquisas e estudos que discutem esta questão - um estudo cuja envergadura contemple de maneira densa esta temática, o que evidencia a existência de uma lacuna a ser devidamente preenchida, face à sua complexidade. Nos anos 30 do século XX, notamos já haver uma significativa utilização do recurso estético do duplo sentido nas formas de enunciação do corpo e da sensualidade das mulheres negras baianas. Iniciamos esse subtópico com O que é que a Baiana tem? composta por Dorival Caymmi em 1939. Assim diz a canção:

O que é que a baiana tem?

O que é que a baiana tem?

Tem torço de seda, tem!

Tem brincos de ouro, tem!

Correntes de ouro, tem!

Tem pano da Costa, tem!

Pulseira de ouro, tem!

Tem saia engomada, tem!

Sandália enfeitada, tem!

Tem graça como ninguém...

Como ela requebra bem...

Quando você se requebrar,

Caia por cima de mim...

Caia por cima de mim...

Caia por cima de mim...

O que é que a baiana tem?

O que é que a baiana tem?

Só vai no Bonfim quem tem...

Só vai no Bonfim quem tem...

Um rosário de ouro

Uma bolota assim.

Quem não tem balangandãs -

Ô ! - não vai no Bonfim,

Ô ! - não vai no Bonfim... 
Nesta letra, percebemos que o corpo e a sensualidade da baiana aparecem nos versos "tem graça como ninguém", "requebra bem" e "caia por cima de mim", numa flagrante enunciação do fascínio e desejo sobre o objeto da narrativa, o corpo da mulher negra. E o compositor resolve: "só vai no Bonfim quem tem", ou seja, para ir ao Bonfim em sua avaliação é preciso ter graça e saber requebrar. Curiosamente, também em 1939, Dircinha Batista interpretou a música $O$ que é que a Baiana tem: esta, composta por Pedro Caetano e Joel de Almeida, como uma espécie de resposta a Caymmi. Na versão, elaborada por Pedro e Caetano, observamos que - como diziam os mais antigos através dos ditos populares - "quem desdenha quer comprar" ou, dito de outra maneira, a forma como a baiana é preterida, desdenhada (em função da carioca) só reforça o lugar ocupado pela primeira no imaginário coletivo da época, inclusive, não apenas entre artistas como aqueles compositores. Assim diz a composição:

Eu quero que me digam o que a baiana tem, Ela pra mim não é melhor que ninguém, Porque a carioca até vestida de chita Andando pela rua é mais bonita.

E não quer cair por cima de ninguém, Não tem balangandãs, porque não lhe convém Pois sendo carioca não precisa de nada, Nem torço de seda, nem sandália enfeitada. Não vai ao candomblé nem gosta de magia, Não usa no pescoço figa de Guiné, E não troca um croquete de confeitaria Por um tabuleiro de acarajé.

Para além dos diversos elementos representativos das práticas culturais das baianas e cariocas que poderiam entrar em concorrência nas análises aqui pretendidas - mas que não vêm ao caso neste momento - notamos que os compositores reivindicam um lugar de destaque e prestígio para as cariocas num contexto em que o Rio de Janeiro, além de ser a capital do país, funcionava como porta de entrada para os ideais de modernidade, urbanidade e civilização dos costumes. Como se pode observar, toda a composição revela o desejo dos compositores em sua representação sobre as cariocas - em preterir as baianas como o tipo desejado no universo onírico masculino, o que pode ser flagrado através do verso "ela pra mim não é melhor do que ninguém", bastante significativo para o que dissemos anteriormente. 
Dessa maneira, somos motivados a pensar nas seguintes questões: como as cariocas viam as baianas naquele contexto? Como se viam a partir das Baianas? De que maneira, em que medida e em quais sentidos, as relações entre as baianas e as cariocas se tornou possível no Rio de Janeiro? Sentiam-se as cariocas preteridas? Quais tipos de estratégias de sedução e encantamento adotaram para notabilizar-se no imaginário masculino? Quais tipos de agenciamento possibilitaria às cariocas ascender à condição de musa nacional?

Em 1962 com Garota de Ipanema de Antônio Carlos Jobim e Vinícius de Moraes, as cariocas parecem ter começado a gozar de um espaço no cancioneiro popular no Brasil, sobretudo e obviamente, entre os compositores da então capital do País, entretanto, as baianas até os anos 90 do século XX ocuparam lugar de relativo destaque como tema-objeto da maioria das composições musicais. Em 1967, Vinícius de Moraes e Baden Powell em Mulher Cario$c a$, registraram:

Ela tem um jeitinho como ninguém,

Que ninguém tem.

A gaúcha tem a fibra.

A mineira o encanto tem.

A baiana quando vibra,

Tem tudo isso e o céu também.

A capixaba é bonita,

É de dar água na boca.

E a linda pernambucana,

$\mathrm{Ai}$, meu Deus, que coisa louca!

A mulher amazonense,

Quando é boa, é demais,

Mas a bela cearense

Não fica nada para trás.

A paulista tem a erva

Além das graças que tem,

A nordestina conserva

Toda a vida e o querer-bem.

A mulher carioca,

O que é que ela tem?

Ela tem tanta coisa

Que nem sabe que tem.

Ela tem o bem que tem.

Tem o bem que tem o bem,

Tem o bem que ela tem,

Que ninguém tem, que tem.

Ela tem um pouquinho que ninguém tem.

Ela faz um carinho como ninguém.

Ela tem um passinho que vai e que vem. 
Ela tem um jeitinho de nhem-nhem-nhem.

A carioca tem um jeitinho de nhem-nhem

Tem o carinho também

A carioca faz um passinho de nhem-nhem-nhem.

Anteriormente nos anos 30, Elisa Coelho interpretou a música Nega Baiana composta por Ary Barroso em 1931, letra na qual o compositor já utilizava o recurso estético do duplo sentido justapondo "corpo e sensualidade", porém acrescentando o elemento "bravura" que também pode ser lido como um atributo de desejo:

Sou nega, nega baiana,

Revolucionária das caatingas do sertão

Sou bamba, no bamboleio,

Ô minhas comidas

É entre os soldados do batalhão

De faca pernambucana

Não vejo home na minha frente

Não vejo, não!

Porém, na hora dos meus pecados,

Ninguém resiste aos meus requebros de sedução!

Não venham de covardia, oi -

Que eu respeito lenço encarnado junto de mim :

Dou tudo pela Bahia.

Só tenho medo de Nosso Senhor do Bonfim.

Notem que nesta composição que, quando Ary Barroso diz "na hora dos meus pecados", está claramente se referindo ao fascínio que o corpo e a sensualidade da "nega baiana" com seus "requebros de sedução" exercia em setores do imaginário masculino da época. À "bravura" da Baiana de Ary Barroso em sua sensualidade corporal, Humberto Porto em Iaiá Baianinha, interpretada por Dalva de Oliveira e a dupla Preto e Branco em 1938, acrescentou os elementos "ardor e dor", assim ditos:

Iaiá baianinha, pimenta de cheiro,

Cheirando a leite de coco, arruda, manjericão,

Machuca, machuca um coração,

Sacode mulata a saia engomada,

E ver assim toda rendada.

Êta, baiana bonita!

Iaiá baianinha que fala gostoso,

Tem voz de juriti, de juriti amoroso,

Que quando morre o dia

Chora saudoso. 
Bate a sandália bem no terreiro, Machuca bem o moreno faceiro. Êta, baiana bonita!

Nesta letra, a Iaiá Baianinha se confunde com os elementos pimenta de cheiro, leite de coco, arruda e manjericão, poeticamente ditos como que capazes de temperar o coração machucado do moreno faceiro. No subtópico a seguir, faremos algumas incursões sobre o binômio "corpo e comida", numa outra forma de enunciar o duplo sentido. Para a apimentada Iaiá Baiana, Pedro de Sá Pereira já havia preparado a solução em Abana, baiana, interpretada por Araci Cortes em 1931:

Baiana, eu dou o meu carinho

Aqui no meu cantinho para quem quiser,

Baiana assim tão desprezada,

Eu dou cocada e tudo mais que aqui houver,

Amendoim torrado.

Baiana lhe encontram no caminho

E muita gente boa faz fé no meu bolinho,

Benzinho, meu tabuleiro, sou desse ioiô,

Com todo orgulho, baiana eu sou.

Abana, baiana,

Abana, abanador,

Fogo, foguinho do meu amor !

Fogo acendeu, fogo apagou,

Cadê a cocada pra meu ioiô ?

Não precisa legenda para que o leitor entender com exatidão a expressão "e muita gente boa faz fé no meu bolinho" quando associada a "fogo acendeu, fogo apagou", elementos de um tipo discursivo sobre uma masculinidade brasileira. Dessa maneira, as Baianas iam se firmando - ou sendo afirmadas - por uma suposta distinção de que gozava, quando comparada às demais mulheres brasileiras. Em Mulata Baiana, composta por Gastão Viana e Pixinguinha e interpretada por Patrício Teixeira em 1938, os compositores disseram:

Mas a mulata baiana, você conhece quem é :

Ela usa sandália bordada na pontinha do pé.

Quando ela passa com seu tabuleiro

Que vem mercando, ioiô, que quer comprar.

E vai efó,

Vai caruru,

Vai acarajé,

Acaçá,

Ioiô quer comprar... 
Quando observado o ano em que as composições musicais foram elaboradas, parece haver a promoção de constantes diálogos, entre os compositores através de suas letras, quando um desdobra, enfatiza ou complementa algum elemento dito por outro anteriormente, ainda que entre as composições musicais haja um relativo distanciamento cronológico. No decorrer dos anos 40, o binômio "corpo e sensualidade" continuou sendo utilizado na música popular do Brasil, sobretudo, nos sambas produzidos no Rio de Janeiro, assim como os diálogos entre os compositores continuaram presentes através das letras que compunham. Senhor do Bonfim me enganou, composta por Pedro Caetano, Wilson Batista e Claudionor Cruz, e gravada por Dircinha Batista e Nuno Roland em 1940, revela

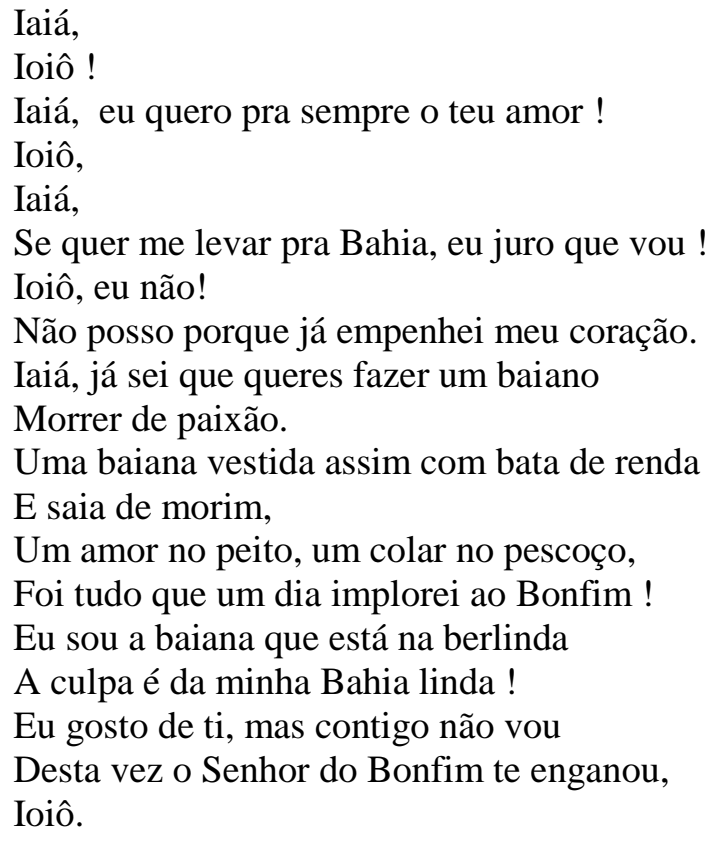

Nos anos 40, decorrente do processo de intensificação da urbanização, modernização e civilização dos costumes na capital do país, entre algumas famílias baianas ali instaladas, se operacionalizou uma espécie de achatamento das condições econômicas, fator que imperou como limitante da possibilidade de permanência. Em 1945, em Mais um milagre, Geraldo Pereira faz alusão a essa questão:
A baiana que eu tanto adorava
Me desenganou
Partiu e não quis mais saber de sambar
Pra mim. 
E agora que eu já nem sonhava

A baiana voltou.

É mais um milagre do Nosso Senhor do Bonfim

Eu tenho em casa, à cabeceira da cama,

Um Senhor do Bonfim,

A quem me queixei e pedi que olhasse

Por mim!

E o senhor soberano e bondoso,

Pra não ver seu filho perdido,

Foi piedoso, atendendo meu pedido.

É muito curioso como no contexto da construção deste tipo de representação, flagramos aspectos do cotidiano das práticas culturais, estivessem elas no âmbito da religiosidade, do sentimento, da ludicidade, da angústia ou todas elas juntas. É emblemático o que diz Dorival Caymmi em Lá vem a baiana, composta em 1947:

\author{
Lá vem a baiana \\ De saia rodada, sandália bordada, \\ Vem me convidar para sambar. \\ Mas eu não vou! \\ Lá vem a baiana, \\ Coberta de contas, pisando nas pontas \\ Achando que eu sou o seu ioiô, \\ Mas eu não vou! \\ Lá vem a baiana, \\ Mostrando os encantos, falando dos santos, \\ Dizendo que é filha do Senhor do Bonfim. \\ Mas pra cima de mim?! \\ Pode jogar seu quebranto que eu não vou ! \\ Pode invocar o seu santo que eu não vou ! \\ Pode esperar sentada, baiana, \\ Que eu não vou! \\ Não vou porque não posso resistir à tentação : \\ Se ela sambar, eu vou sofrer. \\ Esse diabo sambando é mais mulher. \\ E seu deixar, ela faz o que bem quer! \\ Não vou, não vou, não vou, \\ Nem amarrado, porque bem sei: \\ Se ela sambar, \\ Hum, hum, hum, hum \\ Hum, hum, hum, hum!
}

Três décadas mais tarde, em Salvador Osmar Macedo compôs Baiana Brejeira, gravada pelo Trio Elétrico Dodô e Osmar: 
Baiana do olhar brejeiro,

Corpo feiticeiro,

Que dá gosto de ver!

Quisera ser a sua mortalha,

A sua tanga de malha

Para me envolver!

Baiana do olhar brejeiro,

Corpo feiticeiro,

Que dá gosto de ver.

Quisera ser a sua mortalha,

A sua tanga de malha,

Eu quero é você,

Quando atrás do trio passa,

Você causa arruaça,

E no salão, pega, larga, tira a mão :

Pode tudo, não faz mal,

É carnaval.

Guardados os devidos distanciamentos cronológicos entre $O$ que é que a baiana tem? de Dorival Caymmi e Baiana Brejeira de Osmar Macedo, percebemos que invariavelmente o binômio "corpo e sensualidade" foi largamente praticado entre os compositores da música popular do Brasil no período (compreendido entre os anos 30 e 90 do século XX ) para se referir ao corpo das baianas: o que nos possibilita ler - através desse tipo de representação - a importância que aquelas mulheres negras baianas já alcançaram no cancioneiro popular deste país.

\section{CORPO E COMIDA}

Continuando a reflexão, as representações elaboradas no cancioneiro popular do Brasil, em larga medida no Rio de Janeiro e na Bahia sobre o cotidiano das práticas culturais como das festas populares baianas, durante muito tempo, associou o binômio "corpo e comida" como elementos quase que indissociáveis. Tomando como referência essa observação, neste subtópico apresentaremos algumas entre as tantas músicas populares do Brasil, nas quais o duplo sentido é utilizado como estratégia discursiva ou suporte estético para estabelecer associações entre elementos da culinária de matriz africana ao corpo das negras baianas.

$\mathrm{Na}$ formação da cultura afro-brasileira, a culinária de matriz africana passou exercer forte influência no cotidiano degustativo do país por representar, junto como demais elementos 
culturais africanos transladados para as terras do Novo Mundo, a ancestralidade e as tradições africanas fortemente fincadas na religiosidade. Logo, se pode dizer da existência de mais um binômio, mais uma chave de interpretação, a relação entre comida e religiosidade africanas. Porém, para os propósitos deste artigo, não nos aprofundaremos neste último binômio.

Voltando à reflexão, começo essa seção com Ary Barroso que, em Terra de Iaiá composta em 1931, trabalhou o binômio “corpo e comida”. A música, gravada por Silvio Caldas e Elias Coelho, assim diz:

Cocada preta, ioiô, Quem quiser conhecer, O Brasil brasileiro, meu bem, Tem que uma vez ir à Bahia, Se tem, Ver o batuque assim... Ver o Senhor do Bonfim. Mamãezinha que morreu Muita vez me ensinou : Que na Bahia

De Iaiá

E ioiô

Foi que o Brasil nasceu. Chorou, canjiquinha, Acará que mofou

Pra Iaiá e ioiô !

A baiana e feiticeira Tem todo o xodó da brasileira Amor diferente daqui, É o de lá, Doce amor de Iaiá. Nosso Senhor do Bonfim Guarde uma baiana pra mim, Canjiquinha quente sinhá!

Nesta letra, o "doce amor de Iaiá" associa-se à "canjiquinha quente". Na história das relações de gênero no Brasil situadas no âmbito da Casa-Grande (FREYRE, 1958), as negras escravizadas, ou escravas domésticas, tornaram-se vítimas das investidas dos senhores de engenho, num contexto em que a idéia de procriação, defendida na tradição judaico-cristã, impedia as senhoras de engenho de praticar relações sexuais gozosas. Ao contrário, as práticas sexuais - no âmbito da relação entre senhor e senhora de engenho -destinavam-se à procriação, à continuidade e à ampliação da família patriarcal. 
Logo, era entre as escravas domésticas que o ato sexual lascivo, ardente e intenso era buscado entre os senhores e os seus filhos, muitos entre os quais realizaram suas primeiras experiências sexuais com as escravas domésticas. Graças a este fato é que, na história deste país, tornou-se possível construir - em torno das mulheres negras - o mito de serem sexualmente quentes, fogosas e boas de cama, como discutido por Ana Cláudia Lemos Pacheco (2008), em sua tese de doutorado.

No decorrer dos anos 30, outros compositores como Ary Barroso, escreveram composições musicais que articulam e/ou associam o corpo da baiana à comida, mas não a qualquer comida, apenas às do âmbito da culinária das matrizes africanas, aqui denominadas como comidas de azeite, comida baiana, dentre outras formulações possíveis. Numa evidente referência às mulheres negras, em Compra, ioiô, gravada por Chiquinha Jacobina em 1935, Roberto Martins e Waldemar Silva, escrevem:

\author{
Compra ioiô, \\ Mungunzá, aqui há, ôroe vatapá. \\ Tem vatapá, tem caruru, \\ Se ioiô não gostar, também tem angu. \\ Ioiô olha a baiana \\ Que está ao seu lado, \\ Que tem pra oferecer, \\ Só pra você, peixe apimentado. \\ Tem peixe apimentado, \\ Tem cuscus e cocada, \\ Canjiquinha bem quentinha, \\ Compra, ioiô, que está tudo em casa.
}

Notem que através da associação entre "se ioiô não gostar também tem angu" e "só pra você peixe apimentado" o compositor estabelece uma relação de intimidade entre a baiana e seu suposto freguês. Prolongando a relação de intimidade, o compositor resolve: "está tudo em casa". Outra observação. Através deste tipo de composição musical, podemos estabelecer as seguintes problematizações: por que as negras baianas passaram a ser representadas nas letras das músicas como objetos de fácil alcance da realização dos desejos sexuais masculinos no Brasil? Como na história deste país se efetivou o entendimento do corpo da mulher negra como fácil de ser acessado? Do ponto de vista sexual as mulheres negras seriam mais fáceis do que as mulheres não-negras? A crença do acesso fácil ao corpo negro da baiana pode ser lido como uma herança das relações estabelecidas entre as escravas domésticas e os senhores 
de engenho na Casa-Grande? Por que e através de quais suportes ou instrumentos essa questão passou a compor o mito da lascívia feminina negra baiana?

Aurora Miranda em Goma de gomá, letra composta por Herivelto Martins em 1938, diz:

Olha a goma de gomá!

Quem é que vende a Iaiá.

Passa a baiana sorrindo

Com seu tabuleiro gingando,

Batendo a chinela faceira,

Lá vem a baiana mercando.

Olha a goma de gomá,

Como é que é, ô dona,

É goma de gomá?

Nos anos 40 duas composições musicais são significativas desse tipo de associação de duplo sentido entre corpo e comida. A primeira é Vatapá composta por Dorival Caymmi em 1942 e a segunda, Lembranças da Bahia composta no mesmo ano por Geraldo Pereira e Moreira da Silva. Na primeira, temos:

Quem quiser vatapá, ô !

Que procure fazê :

Primeiro o fubá,

Depois o dendê.

Procure uma nega baiana, ô

Que saiba mexê,

Que saiba mexê,

Que saiba mexê!

Bota castanha de caju,

Um bucadinho mais,

Pimenta malagueta,

Um bucadinho mais !

Amendoim, camarão, rala o coco,

Na hora de machucar!

Sal com gengibre e cebola, Iaiá,

Na hora de temperar.

Não pára de mexê, ô !

Que é pra não embolar.

Panela no fogo,

Não deixa queimar.

Com qualquer dez mil-réis e uma nega, ô !

Se faz um vatapá,

Se faz um vatapá,

Se faz um vatapá. 
Aqui facilmente o leitor pode identificar a ambivalência quando o compositor associa os versos "procure uma nega baiana" com "que saiba mexê" e completa a associação com "bota", "um bucadinho mais", "na hora de temperar", "não pára de mexê" e "que é pra não embolar”. Na segunda composição, ainda que de maneira aparentemente mais sutil como que nas entrelinhas, notamos a construção do duplo sentido:

Quando eu desembarquei na Bahia, Linda baianinha de sandália no pé Já me esperava cheia de alegria, Com uma figa no pescoço feita de guiné, E me disse:

Temos uma igreja que hoje festeja O dia do Bonfim .

E perguntei onde era, e fomos lá Ver ioiô e iaiá, sambando, oi, pra mim. E nessa terra de baianas e bons moços, Mil virtudes encontrei por lá.

Tive convites para bons almoços, Comi efó, também comi vatapá, Acarajé, xinxim apimentado, Com as peixadas com arroz e caruru, E ainda assim com sabor nos lábios, No jenipapo, da canjica e do angu.

Em 1944, Pregão da Baiana, composta por Denis Brean e gravada por Isaura Garcia assim assinala:

Quando eu tenho uma vontade

De comer qualquer quitute,

Eu procuro o tabuleiro de sinhá,

Seu ponto é lá na rampa do mercado,

Com o tabuleiro armado fazendo o seu pregão:

Tem cuscus para ioiô,

E também para iaiá !

Tá quentinho, tá gostoso,

Se quiser pode provar.

No tabuleiro a gente

Encontra o que quiser,

Pamonha, caruru,

Vatapá e o acaçá

Azeite de dendê e acarajé

Pé-de-moleque, o bom efó e o mungunzá.

Mas a arte de sinhá está no prato,

E este prato é o cuscus de camarão,

Com quitutes e a arte do fogão, 


\section{É que sinhá se serve pra pegar um coração.}

Através do arremate dos versos "com quitutes e a arte do fogão" e "é que sinhá se serve pra pegar um coração", mais uma vez percebemos como o binômio "corpo e comida" foram utilizados recorrentemente entre os compositores como recurso estético para dizer sobre a atratibilidade e fascínio que o corpo das baianas exerciam no imaginário masculino daqueles compositores da música popular do Brasil.

\section{CORPO E RELIGIOSIDADE}

Fechando a proposição temática deste artigo, qual seja, discutir, ainda que introdutoriamente como o duplo sentido enquanto recurso estético foi utilizado entre alguns compositores na música popular do Brasil, apresentaremos a terceira chave que é a associação entre o corpo das baianas à religiosidade. Em larga medida, podemos dizer que a relação entre baianas e religiosidade estabelecida no cancioneiro popular do Brasil recai quase sempre na associação entre o corpo da baiana ao Senhor do Bonfim, sobretudo entre as composições que se referem à igreja, à Lavagem e à Festa do Senhor do Bonfim de Salvador, tradição religiosa inventada a partir do ano de 1745 pelo Capitão de Mar e Guerra da Marinha Portuguesa, Theodózio Rodrigues de Faria, tema já desenvolvido em outro estudo (NUNES NETO, 2013).

Neste sentido, as composições que serão apresentadas a seguir, de alguma maneira, corroboram com a relação que, até aqui, temos estabelecido referência: a utilização do recurso estético do duplo sentido para referir-se ao corpo das negras baianas. Em 1944 Francisco Alves gravou Oração ao Bonfim composta por Vicente Paiva e Chiquinho Sales:

\footnotetext{
Eu vou fazer uma oração Ao Senhor do Bonfim, ô, ô, Pra dar vida a esta baiana Que é tudo pra mim, ô, ô, Que tem no olhar a candura, E no riso a doçura, E abençoe o nosso amor. Eu vou fazer uma oração Ao Senhor do Bonfim, ô, ô, E ele por certo ouvirá Minha prece de fé. Com os olhos voltados pro céu, Deposito a minha devoção,
} 
Ó Senhor do Bonfim,

Esperança do meu coração.

Linda boneca, sem vida e sem cor,

Anda depressa para o nosso amor,

Na sua boca a ânsia louca de mil beijinhos dar,

Quero dos seus beijos sentir o calor.

Quero dos seus lábios sentir o dulçor,

Vem para o amor,

Pra da vida sentir o prazer,

Vem meu amor,

Vem viver.

Dez anos depois, "O Trio de Ouro" em 1954 gravou A Baiana sambou composta por Herivelto Martins e Ciro Monteiro. Assinala o compositor:
A baiana sambou,
Remexeu tanto,
Que eu tive que ir ao Bonfim,
Rezei uma prece, pedi que me desse
Aquela baiana todinha pra mim.
Aí, Senhor do Bonfim não negou.
Aí, Senhor do Bonfim me entregou
Aquela baiana todinha pra mim!

Em Salvador, na tradição em que se celebra o Senhor do Bonfim e Oxalá na Festa do Senhor do Bonfim, as baianas, integrantes da tradição ao culto do Senhor da Colina, dela tomam parte, compondo uma espécie de tríade: relação que, juntamente com eles, se consagraram como emblemático ícone da Festa. Como dito na composição musical, Terreiros e Catedrais, de Moraes Moreira e Béu Machado, as baianas funcionam como vetor através do qual, em Salvador, terreiros e catedrais dialogam. Em Bahia de todos os deuses composta por Bala e Manuel em 1969 e interpretada por Elza Soares no mesmo ano, os compositores revelam:

Bahia, os meus olhos estão brilhando

Meu coração palpitando,

De tanta felicidade.

És a rainha da beleza universal,

Minha querida Bahia.

Muito antes do Império,

Foi a primeira capital,

Bahia, Bahia

Preto Velho Benedito já dizia :

Felicidade também mora na Bahia.

Sua história, sua glória, seu nome 


\section{É tradição.}

Bahia do velho mercado,

Subida da Conceição.

És tão rica em minerais

Tem cacau, tem carnaúba,

Famoso jacarandá.

Terra abençoada pelos deuses

E o petróleo a jorrar.

Nega baiana, tabuleiro de quindim,

Todo dia ela está, na igreja do Bonfim, oi !

$\mathrm{Na}$ ladeira tem, tem capoeira....

Zum, zum, zum

Zum, zum, zum

Capoeira mata um.

As baianas e o Senhor do Bonfim atravessaram todo o século XX, costumeiramente representados na música popular do Brasil. Paulinho Boca de Cantor gravou em 1990 Terreiros e Catedrais composta por Moraes Moreira e Béu Machado, numa clara referência às discussões sobre o sincretismo religioso na Bahia:

Meu Senhor do Bonfim,

Meu começo!

Reconheço, Senhor Oxalá,

Se vem chuva

Pra planta crescer.

Trago água de flor

Pra te dar!

Sexta-feira é dia de branco,

Pele negra,

Colina e colar.

Trago rezas e incenso

Pro santo!

Canto e danço

Pro meu orixá.

Da Conceição ao Bonfim

Quem tem fé vai a pé: ora veja

Vão lavar a escada

Da igreja

Baianas do Candomblé !

$\mathrm{Na}$ Bahia é assim :

O que vale é a fé,

Nada mais .

Vão subindo

A ladeira, se unindo

Terreiros e catedrais 
Assim, concluindo este breve artigo, notamos que a partir de finais dos anos 90 os discursos - ou as representações regionalistas - sobre a figura feminina na música popular do Brasil acrescentaram outros dispositivos, outros elementos, outras formas de representar as mulheres, como se pode notar em composições musicais do pagode baiano e, igualmente, no funk carioca. Estes gêneros musicais passaram, então, a dizer as mulheres não mais como negras, mulatas, sararás ou loiras, mas como pertencentes a uma mesma unidade discursiva, homogeneizante, totalizadora e sem distinções tão aparentes, promovendo, desta forma, uma espécie de nivelamento, pelo menos no âmbito discursivo, como se entre elas não houvessem especificidades culturais, regionais e locais, num país como o Brasil (tamanha é a sua diversidade cultural).

Tanto entre as composições musicais do pagode produzido na Bahia quanto nos funks produzidos no Rio de Janeiro, constatamos, lamentavelmente, que as mulheres, agora niveladas, sejam brancas, negras, mulatas ou mestiças, passaram a ser depreciadas e subjugadas aos desejos masculinos que as tratam, indistintamente, como meros objetos para a realização de fantasiais sexuais ou reafirmação da condição de uma suposta masculinidade, o que nos mobiliza a pensar na seguinte questão: será que estamos vivenciando uma espécie de empobrecimento musical na forma de enunciar o desejo pelo corpo feminino, na música popular, produzida no Brasil? Um convite aos leitores e leitoras a refletirem sobre esse problema.

\section{REFERÊNCIAS}

CHARTIER, Roger. A História Cultural: entre práticas e representações. Rio de janeiro: Bertrand Brasil, 1990.

FREYRE, Gilberto. Casa-Grande \& Senzala: formação da família brasileira sob o regime de Economia Patriarcal. $9^{\text {a }}$ ed., Rio de Janeiro: José Olympio, 1958.

GINZBURG, Carlo. O queijo e os vermes. São Paulo: Cia ds Letras, 1998.

Jornal Diário de Notícias. 13 de janeiro de 1968.

MOURA, Roberto. Tia Cita e A Pequena África no Rio de Janeiro. $2^{\mathrm{a}}$ edição, Rio de Janeiro: 
Secretaria Municipal de Cultura/Departamento Geral de Documentação e Informação Cultural/Divisão de Editoração, 1995. (Coleção Biblioteca Carioca)

NUNES NETO, Francisco Antonio. A invenção de uma tradição: a Festa do Senhor do Bonfim em jornais baianos. Salvador: UFBA-IHAC, 2014. (Tese de Doutorado)

. A invenção da tradição: a devoção ao Senhor Bom Jesus do Bonfim na/da Bahia. In: Revista Interfaces Científicas - Humanas e Sociais. Aracajú. Vol. 1, nº 2, p. 45-55, fev. 2013. www.periodicos.set.edu.br

As mulheres de saia como ícones identitários e de identificação em Salvador: trajetórias femininas negras em Salvador. In: Revista Interfaces Científicas - Humanas e Sociais. Aracajú. Vol. 1, no 3, p. 40-50, jun. 2013. www.periodicos.set.edu.br

PACHECO, Ana Claúdia Lemos. "Branca para casar, Mulata para f..., Negra para trabalhar": Escolhas afetivas e significados de solidão entre mulheres negras em Salvador, Bahia. Tese de Doutorado apresentada ao Programa de Pós-Graduação em Ciências Sociais da Universidade Estadual de Campinas (Unicamp)/Instituto de Filosofia e Ciências Humanas (IFCH), 2008.

SANCHES, Maria Aparecida Prazeres. Fogões, Pratos e Panelas: poderes, práticas e relações de trabalho doméstico, Salvador 1900-1950. Dissertação de Mestrado apresentada ao Programa de Pós-Graduação em Ciências Sociais da Faculdade de Filosofia e Ciências Humanas, FFCH/UFBA, 1998.

SANTANNA, Marilda. As donas do canto. O sucesso das estrelas-intérpretes no carnaval de Salvador. Salvador: EDUFBA, 2009.

Recebido em: 11 de novembro de 2013.

Aprovado em: 05 de dezembro de 2013. 